\title{
Cranial cooling during firefighting recovery effects on physiological and perceptual strain
}

\author{
Stephen S Cheung ${ }^{1 *}$, Phillip J Wallace', Anais Masbou' ${ }^{1}$, Stewart R Petersen ${ }^{2}$ \\ From 15th International Conference on Environmental Ergonomics (ICEE XV) \\ Portsmouth, UK. 28 June - 3 July 2015
}

\begin{abstract}
Introduction
We performed a firefighting simulation of repeated work-rest bouts while wearing fire-fighting ensemble (FFE) and self-contained breathing apparatus (SCBA) in the heat, removing the helmet and SCBA during recovery and comparing cranial cooling $(\mathrm{CC})$ versus passive $(\mathrm{CON})$ exposure. We hypothesized that $\mathrm{CC}$ would better counteract heat storage compared to passive cooling.
\end{abstract}

\section{Methods}

Eleven males (mean (SD), 30.9 (9.2) y, $49.5(5.1) \mathrm{mL} . \mathrm{kg}^{-1} \cdot \mathrm{min}^{-1}$ $\left.\dot{\mathrm{V}} \mathrm{O}_{2 \text { peak }}\right)$ performed two trials consisting of $2 \times 20 \mathrm{~min}$ bouts of treadmill walking $\left(5.6 \mathrm{~km} \cdot \mathrm{h}^{-1}, 4 \%\right.$ incline) in $35^{\circ}$ $\mathrm{C}$ and $60 \%$ relative humidity while wearing full FFE and SCBA, with 20 min passive recovery between each exercise bout. During recovery, participants sat in the chamber and removed gloves, helmet, fire hood, and SCBA, but the jacket remained buttoned up. For CC, a close-fitting custom liquid-perfused hood pumped $13^{\circ} \mathrm{C}$ water at a rate of $\sim 500 \mathrm{~mL} \cdot \mathrm{min}^{-1}$ through the head and neck regions. For $\mathrm{CON}$, participants performed the same recovery but the hood was not perfused to simulate wearing the fire hood and helmet. Rectal temperature $\left(\mathrm{T}_{\mathrm{re}}\right)$, heart rate $(\mathrm{HR})$, and ventilation $\left(\dot{\mathrm{V}}_{\mathrm{E}}\right)$ were continuously recorded throughout exercise and recovery, while subjective ratings of perceived exertion (RPE), thermal comfort (TC), and breathing stress (BrS) were obtained every 4-5 min during exercise and recovery. Significance was set at $\mathrm{p}=0.05$.

\section{Results}

All participants successfully completed the first exercise bout, with no differences in any variable prior to the

\footnotetext{
* Correspondence: scheung@brocku.ca

'Environmental Ergonomics Laboratory, Department of Kinesiology, Brock University, Ontario, Canada

Full list of author information is available at the end of the article
}

experimental recovery manipulation. Rectal temperature rose in both $\mathrm{CC}\left(0.11 \pm 0.19^{\circ} \mathrm{C}\right.$,) and $\mathrm{CON}\left(0.26 \pm 0.15^{\circ} \mathrm{C}\right)$ during Rest, with non-significant interaction between conditions $(\mathrm{p}=0.076)$. During Rest, neck temperature was lower in CC compared to CON from 4 min (CC: $35.73 \pm$ $\left.3.28{ }^{\circ} \mathrm{C}, \mathrm{CON}: 37.66 \pm 1.35{ }^{\circ} \mathrm{C}, \mathrm{p}=0.025\right)$ until the end (CC: $33.06 \pm 4.70{ }^{\circ} \mathrm{C}, \mathrm{CON}: 36.85 \pm 1.63{ }^{\circ} \mathrm{C}, \mathrm{p}=0.014$ ). $\mathrm{HR}$ significantly decreased over recovery in both $\mathrm{CC}$ and $\mathrm{CON}$, with no significant differences between conditions. Perceptually, TC was significantly lower in CC at $5 \mathrm{~min}, 10 \mathrm{~min}$, $15 \mathrm{~min}$, and $20 \mathrm{~min}$ time points during the Rest period compared to CON. There were no significant differences in tolerance times (voluntary termination or $\left.\mathrm{T}_{\mathrm{re}}=40{ }^{\circ} \mathrm{C}\right)$ between CC (16.55 (1.14) min) and the CON (16.60 (1.31) min). $\mathrm{T}_{\text {re }}$ was not significantly different at the start (CC: $38.3(0.40){ }^{\circ} \mathrm{C}, \mathrm{CON}: 38.40$ $(0.16){ }^{\circ} \mathrm{C}$ ) and at the end (CC: $38.82(0.23){ }^{\circ} \mathrm{C}, \mathrm{CON}$ : $\left.39.07(0.22){ }^{\circ} \mathrm{C}\right)$ of Exercise2. HR was not significantly different at the start (CC: 149 (17.6) b. $\mathrm{min}^{-1}, \mathrm{CON}: 157$ (15.6) b. $\mathrm{min}^{-1}$ ) and at the end (CC: 162 (18.76) b. $\mathrm{min}^{-1}$, CON: 174 (12.13) b. $\mathrm{min}^{-1}$ ) of Exercise2. Total $\mathrm{V}_{\mathrm{E}}$ during Exercise 2 was similar between CC (1146.3 (331.9) L) and CON (1173.3 (307.0) L) as was BrS and RPE.

\section{Discussion}

The face and head has a high alliesthesial thermosensitivity [1], but Tyler et al. proposed [2] that a sufficient thermal strain threshold was necessary for neck cooling to be effective. However, our high rate of heat stress potentially overwhelmed any cooling benefit from $\mathrm{CC}$, as any attenuation in physiological and perceptual responses was transient. Thermal hyperpnea was also not alleviated by $\mathrm{CC}$, with no effect on ventilatory demands and air usage. While head and neck cooling during recovery may attenuate thermal discomfort, it is not an effective strategy to decrease the rate of physiological strain or extend 
tolerance time during heavy exercise in the heat when recovery is performed while largely encapsulated.

\section{Authors' details}

${ }^{1}$ Environmental Ergonomics Laboratory, Department of Kinesiology, Brock University, Ontario, Canada. ${ }^{2}$ Faculty of Physical Education and Recreation,

University of Alberta, Canada.

Published: 14 September 2015

\section{References}

1. Tyler CJ, Wild P, Sunderland C: Practical neck cooling and time-trial running performance in a hot environment. Eur J Appl Physiol 2010, 110:1063-1074.

2. Cotter JD, Taylor NAS: The distribution of cutaneous sudomotor and alliesthesial thermosensitivity in mildly heat-stressed humans: An openloop approach. J Physiol 2005, 565:335-345.

doi:10.1186/2046-7648-4-S1-A1

Cite this article as: Cheung et al: Cranial cooling during firefighting recovery effects on physiological and perceptual strain. Extreme Physiology \& Medicine 2015 4(Suppl 1):A1.

\section{Submit your next manuscript to BioMed Central} and take full advantage of:

- Convenient online submission

- Thorough peer review

- No space constraints or color figure charges

- Immediate publication on acceptance

- Inclusion in PubMed, CAS, Scopus and Google Scholar

- Research which is freely available for redistribution

Submit your manuscript at www.biomedcentral.com/submit
C Biomed Central 